Research Article

\title{
CHROMIUM AND ITK FORMULATION DIMINISH ARSENIC-INDUCED KIDNEY INJURY IN OBESE TYPE-2 DIABETIC RATS
}

\author{
Mohd. Saif, Raut Akash, Virendra Pratap Yadav, Rajneesh Singh, Atul Prakash, Amit Shukla, \\ Soumen Choudhury* \\ Received 03 November 2021, revised 20 December 2021
}

\begin{abstract}
The present study was designed to evaluate the effect of pre-exposure to arsenic and chromium either alone or in combination for 90 days on renal dysfunctions associated with type-2 obese diabetes. Further, an attempt was made to assess the ameliorative potential of ITK (Indian Traditional Knowledge) formulation against these disorders. Induction of diabetes in obese rats significantly $(p<0.05)$ increased the fasting blood glucose levels which were further increased in arsenic pre-exposed animals. Significant elevation in the kidney injury biomarkers (serum BUN, serum creatinine, urinary albumin, creatinine) were also observed in these groups of animals. In addition, the mRNA expression of cystatin-3 in kidney tissues was significantly $(\mathbf{p}<0.05)$ increased in the arsenic pre-exposed animals. On the other hand, pre-exposure to chromium produced nephro-protective effect as evidenced by the improvement in altered biomarkers of kidney injury. Further, chromium was also found to reduce or dampen the arsenic-induced kidney injury when administered concurrently in obese diabetic rats. Oral administration of one ITK formulation also supported the nephro-protective effect of chromium and may be recommended to reduce diabetes associated complication.
\end{abstract}

Key words: Type2 diabetes, Arsenic, Chromium, ITK formulation, Kidney injury, Rats.

\section{INTRODUCTION}

Diabetes mellitus (DM), commonly referred as diabetes, is a metabolic disorder characterised by high blood sugar levels over a prolonged period of time along with frequent urination and unexplained weight loss (Zimmet et al. 2001). The chronic state of hyperglycaemia leads to disturbance in the homeostatic systems of storage and mobilization of metabolic fuels including carbohydrate, fat and protein associated with absolute or relative deficiency in insulin secretion and/or its action (Nicolle et al. 2011). This global diabetes epidemic is chiefly due to type 2 diabetes as it makes up more than 90\% of all diabetes cases (Tripathi and Srivastava 2006). Long-term complications from high blood sugar include heart disease, strokes, kidney failure, diabetic retinopathy leading to blindness (Zimmet et al. 2001). Diabetic nephropathy (DN) is reported to develop in 30$40 \%$ of patients with T2DM and has become a leading cause of end stage renal failure and death worldwide
(Schena and Gesualdo 2005, Tanios and Ziyadeh 2012, Lizicarova et al. 2014).

Metals are inorganic elements occurring naturally and are present in small amount in living tissue and some of them (e.g. $\mathrm{Mg}, \mathrm{Mn}, \mathrm{Cr}, \mathrm{Fe}$ and $\mathrm{Cu}$ etc.) are essential for maintaining some important biochemical pathways (Khan and Awan 2014). Chromium enhances the insulin receptor activity on target tissue, especially in muscle cells. Various studies have also reported that imbalance in these essential metals might adversely affect pancreatic islets and causes development of diabetes. On the other hand, toxic metals namely $\mathrm{Pb}, \mathrm{Ni}, \mathrm{Cd}$ and $\mathrm{As}$ were reported to be adequately present in the biological samples of type 2 diabetic patients and were associated with abnormal glucose uptake and altered glucose metabolism (Khan and Awan 2014). Human beings and animals are exposed to these toxic heavy metals from various man-made processes through contaminated water, air, soil and food and causes physiological, biochemical and histological disorders.

Department of Veterinary Pharmacology and Toxicology, College of Veterinary Science \& Animal Husbandry, U.P. Pandit Deen Dayal Upadhayaya Pashu Chikitsa Vigyan Vishwavidhyalaya Evam Go- Anusandhan Sansthan, Mathura (U.P.), India. "Corresponding author. e-mail: chsoumenpharma@gmail.com 
Ground water contamination with arsenic is becoming an alarming threat for human beings and livestock throughout the world and is reported to be associated with several disorders like cancer and diabetes. Arsenic disrupts the glucose metabolism by modulating the signalling pathways of tumor necrosis factor-alpha (TNF$\propto$ ), mitogen activated protein kinase (MAP-kinase) and/ or modulation of translocation of GLUT-4 to membrane which are mainly mediated by modulation of signal transduction factors including $\mathrm{NF}_{\mathrm{K}} \mathrm{B}, \mathrm{p} 38$ mitogenactivated protein kinase (MAPK), tumor necrosis factor$\propto(\mathrm{TNF} \propto)$, phosphatidydylinositol-3-kinase (Somwar $e t$ al. 2002, Walton et al. 2004, Sriwijitkamol et al. 2006). On the other hand, trivalent form of chromium is reported to up-regulate glucose transporter (GLUT-4) translocation and thereby facilitating the glucose uptake. Thus, deficiency of chromium is reported to cause diabetes and associated complications (Khan and Awan 2014). However, their effect of diabetes-induced nephropathy is poorly understood.

Indigenous Traditional Knowledge (ITK) is the knowledge that people in a given community has developed over time and continues to develop it based on their experience over a long period of time, and which has been adapted to local culture and environment (Ghosh and Sahoo 2011). Globally, the concept of ITK formulations gained recognition through the World Conservation Strategy of International Union and Conservations of Natural Resources in 1980 followed by World Commission on Environment and Development, 1987 and United Nations Conference on Environment and Education in 1992 which recognized the existence of unique traditional knowledge in every culture, society and country. Since India has a long history and much enriched culture, there is abundant reservoir of indigenous knowledge in every part of the country (Pandey et al. 2017).

The ITK formulation used in the present study was composed of wheat, black cumin, barley and gum acacia. The phenolic compounds present in wheat (Triticum aestivum L.) have promising antioxidant, antiinflammatory, anti-apoptosis properties (Ward et al. 2008,

Table 1. Different groups of animals used in present study.

\begin{tabular}{|c|c|c|}
\hline Groups & Description & Treatment \\
\hline Gr-I & Control (C) & Normal saline solution orally for 150 days \\
\hline Gr-II & Obese Control (O) & Exposure to HFD and normal saline solution orally for 90 days \\
\hline Gr-III & $\begin{array}{l}\text { Obese + Diab. } \\
(\mathrm{O}+\mathrm{D})\end{array}$ & $\begin{array}{l}\text { Exposure to HFD and normal saline solution orally for } 90 \text { days, and i.p. administration } \\
\text { of STZ on } 90^{\text {th }} \text { day }\end{array}$ \\
\hline Gr-IV & $\begin{array}{l}\text { Obese }+ \text { Diab. }+ \text { As } \\
(\mathrm{O}+\mathrm{D}+\mathrm{As})\end{array}$ & $\begin{array}{l}\text { Exposure to arsenic (@38 ppb) in drinking water and feeding of HFD for } 90 \text { days, i.p. } \\
\text { administration of STZ on } 90^{\text {th }} \text { day }\end{array}$ \\
\hline Gr-V & $\begin{array}{l}\text { Obese }+ \text { Diab. }+ \text { As }+ \text { ITK } \\
(\mathrm{O}+\mathrm{D}+\mathrm{As}+\mathrm{ITK})\end{array}$ & $\begin{array}{l}\text { Exposure to arsenic (@38 ppb) in drinking water and feeding of HFD for } 90 \text { days, i.p. } \\
\text { administration of STZ on } 90^{\text {th }} \text { day, administration of ITK orally (@ } 3 \mathrm{ml} / \mathrm{kg} \text { b. wt.) daily } \\
\text { from } 90-150^{\text {th }} \text { day }\end{array}$ \\
\hline Gr-VI & $\begin{array}{l}\text { Obese }+ \text { Diab. }+ \text { Cr } \\
(\mathrm{O}+\mathrm{D}+\mathrm{Cr})\end{array}$ & $\begin{array}{l}\text { Exposure to chromium (@ } 1 \mathrm{ppm} \text { ) in drinking water and feeding of HFD for } 90 \text { days, } \\
\text { i.p. administration of STZ on } 90^{\text {th }} \text { day }\end{array}$ \\
\hline Gr-VII & $\begin{array}{l}\text { Obese }+ \text { Diab. }+\mathrm{Cr}+\mathrm{ITK} \\
(\mathrm{O}+\mathrm{D}+\mathrm{Cr}+\mathrm{ITK})\end{array}$ & $\begin{array}{l}\text { Exposure to chromium (@ } 1 \text { ppm) in drinking water and feeding of HFD for } 90 \text { days, } \\
\text { i.p. administration of STZ on } 90^{\text {th }} \text { day, administration of ITK orally (@ } 3 \mathrm{ml} / \mathrm{kg} \mathrm{b} \text {. wt.) } \\
\text { daily from } 90-150^{\text {th }} \text { day }\end{array}$ \\
\hline Gr-VIII & $\begin{array}{l}\text { Obese }+ \text { Diab. }+ \text { As }+ \text { Cr } \\
(\mathrm{O}+\mathrm{D}+\mathrm{As}+\mathrm{Cr})\end{array}$ & $\begin{array}{l}\text { Concurrent exposure to arsenic (@ } 3 \text { ppb) and chromium (@ } 1 \text { ppm) in drinking water } \\
\text { and feeding of HFD for } 90 \text { days, i.p. administration of STZ on } 90^{\text {th }} \text { day }\end{array}$ \\
\hline Gr-IX & $\begin{array}{l}\text { Obese }+ \text { Diab. }+ \text { As }+ \text { Cr }+ \\
\text { ITK }(\mathrm{O}+\mathrm{D}+\mathrm{As}+\mathrm{Cr}+ \\
\text { ITK })\end{array}$ & $\begin{array}{l}\text { Concurrent exposure to arsenic (@ } 3 \text { ppb) and chromium (@1 ppm) in drinking water } \\
\text { and feeding of HFD for } 90 \text { days, i.p. administration of STZ on } 90^{\text {th }} \text { day, administration } \\
\text { of ITK orally (@ } 3 \mathrm{ml} / \mathrm{kg} \text { b. wt.) daily from } 90-150^{\text {th }} \text { day. }\end{array}$ \\
\hline
\end{tabular}


Vaher et al. 2010). Black cumin (Nigella sativa) has a wide range of pharmacological and biological activities including antihypertensive, antidiabetic, diuretics, anticancer, immunomodulator, analgesic, antioxidant, antimicrobial, anti-inflammatory, nephro-protective, gastro-protective, antioxytocic and anticonvulsant properties (Ahmad et al. 2013). $\beta$-glucan from cereals like barley has strong cholesterol and triglyceride lowering properties leading to reduced cardiovascular diseases (Lee et al. 2010). It modifies properties of chyme in the upper part of the gastrointestinal tract affecting gastric emptying, gut motility and nutrient absorption, which are reflected in lower postprandial glycemic and insulin responses because of its soluble fiber with viscous nature (Behall et al. 2006). Gum arabic is a soluble fermentable fiber and has shown hypoglycemic, antioxidant effects and also enhanced lipid metabolism in previous studies (Ali et al. 2009). Arabic gum by initiating the release of insulin from pancreatic beta cells, showed a significant hypoglycemic effect (Grover et al. 2002, El-Nagar 2017).

Though the effect of arsenic and chromium on renal disease has been reported, their potential role in modulating these diabetes-associated complications is largely unknown. Thus, the present study is aimed to evaluate the role of arsenic and chromium in diabetesinduced nephropathy as well as the efficacy of ITK formulations to ameliorate this diabetes-associated disorder.

\section{MATERIALS AND METHODS}

\section{Experimental animals}

Healthy adult male Wistar rats (160-170 g) were procured from Disease Free Small Animal House, LUVAS, Hisar, India. Rats were housed in polypropylene cages under 12-12 h dark-light cycle with free access to water and pelleted feed purchased from M/s Ashirwad Industries, Chandigarh, Punjab, India. They were acclimatized for a period of one week in the departmental laboratory animal house. The rats were randomly divided in nine groups having ten animals per group and subjected to different treatments as described in Table 1.

All the experimental protocols were undertaken following approval of the Institutional Animal Ethics Committee (IAEC) (Approval No.: IAEC/18/19 via letter No. 121/IAEC/18 Dated 25.09.2018).

\section{Preparation of high fat diet}

High fat diet (HFD) was prepared in our laboratory as described earlier (Suman et al. 2015) with minor modifications. Briefly, HFD was prepared by using normal pelleted feed (365 g), lard (310 g), mixture of vanaspati ghee and coconut oil in ratio of $2: 1(50 \mathrm{~g})$, soyabean chunks and/or milk powder (250 g), yeast powder (1 g), sodium chloride (1 g), dl-methionine (3 g) and vitamin and mineral supplement (20 $\mathrm{ml}$ as syrup). All ingredients were mixed together and the mixture was then kept into a freezer to solidify before bringing them at room temperature. The mixture was then given to rats ad-libitum for a period of three months.

\section{Preparation of hot aqueous extract of ITK formulation}

For preparation of ITK formulation, $100 \mathrm{~g}$ each of ingredients viz. gum acacia, black cumin, wheat and barley were weighed and washed with fresh water. The ingredients together were soaked in water $(300 \mathrm{ml})$. The mixture was heated up on a normal flame. The mixture was kept on flame for five minutes after start of boiling. After coming down at room temperature, the mixture was filtered using a sieve and the extract obtained (around 50 ml) was kept in air tight containers at $4{ }^{\circ} \mathrm{C}$ for further use. ITK formulation was given after 90 to 150 days, when diabetes was induced by Streptozotocin (STZ).

\section{Type-2 diabetic model in rats}

HFD-diet induced obese diabetic model was adopted as described earlier with some modification (Reed et al. 2000, Srinivasan et al. 2005). The HFD-fed obese rats were used for induction of diabetes at 90 days by injecting single dose of streptozotocin (@30 mg/kg b. Wt. i.p.). The dose of the streptozotocin was selected based on the

Table 2. Description of the primers.

\begin{tabular}{llccl}
\hline Gene & Primer Sequence & Amplicon size (bp) & Annealing Temp. $\left({ }^{\circ} \mathbf{C}\right)$ & Reference \\
\hline Cyst-3 & F5'-GCGTACCACAGCCGCGCCAT-3' & 149 & 63.2 & $\begin{array}{l}\text { Suzuki } \text { et al. } \\
(2014)\end{array}$ \\
& F-5'TGGGGCTGGTCATGGAAAGGACAGT-3' & & & $\begin{array}{l}\text { Turchetti et } \\
\text { al. }(2015)\end{array}$ \\
\hline
\end{tabular}


Table 3. Effect of pre-exposure to arsenic and chromium either alone or in combination on fasting blood glucose level in obese diabetic rats after administration of STZ (@30 mg/kg b.wt.).

\begin{tabular}{|c|c|c|c|c|c|c|c|}
\hline \multirow[t]{2}{*}{ Group } & \multirow[t]{2}{*}{ Description } & \multicolumn{6}{|c|}{$\begin{array}{c}\text { Fasting blood glucose (mg/dl) } \\
\text { After administration of STZ (@30 mg/kg b.wt.) }\end{array}$} \\
\hline & & 0 day & $3^{\text {rd day }}$ & $15^{\text {th }}$ day & $30^{\text {th }}$ day & $45^{\text {th }}$ day & $60^{\text {th }}$ day \\
\hline I & $\mathrm{C}$ & $100.50^{\mathrm{d}} \pm 0.56$ & $106.60^{\mathrm{e}} \pm 0.45$ & $89.60^{g} \pm 0.63$ & $99.70^{g} \pm 0.84$ & $109.90^{\mathrm{g}} \pm 0.80$ & $101.00^{\mathrm{h}} \pm 0.77$ \\
\hline II & $\mathrm{O}$ & $115.70^{\mathrm{a}} \pm 0.47$ & $105.10^{\mathrm{e}} \pm 0.40$ & $98.30^{f} \pm 0.61$ & $101.50^{\mathrm{g}} \pm 1.10$ & $105.70^{\mathrm{g}} \pm 0.57$ & $111.00^{\mathrm{g}} \pm 0.47$ \\
\hline III & $\mathrm{O}+\mathrm{D}$ & $110.90^{\mathrm{b}} \pm 0.54$ & $311.70^{\mathrm{d}} \pm 3.57$ & $259.70^{e} \pm 3.28$ & $299.10^{b} \pm 2.21$ & $279.50^{b} \pm 2.49$ & $253.50^{b} \pm 2.22$ \\
\hline IV & $\mathrm{O}+\mathrm{D}+\mathrm{As}$ & $112.10^{\mathrm{b}} \pm 0.70$ & $344.20^{b} \pm 1.20$ & $270.20^{\mathrm{d}} \pm 0.87$ & $340.90^{\mathrm{a}} \pm 1.12$ & $326.10^{\mathrm{a}} \pm 0.72$ & $301.00^{\mathrm{a}} \pm 1.14$ \\
\hline $\mathrm{V}$ & $\mathrm{O}+\mathrm{D}+\mathrm{As}+\mathrm{I}$ & $104.80^{c} \pm 0.61$ & $356.20^{\mathrm{a}} \pm 0.94$ & $326.40^{\mathrm{a}} \pm 0.76$ & $282.70^{\mathrm{d}} \pm 0.95$ & $262.50^{c} \pm 1.03$ & $234.50^{c} \pm 0.92$ \\
\hline VI & $\mathrm{O}+\mathrm{D}+\mathrm{Cr}$ & $95.60^{\mathrm{e}} \pm 0.52$ & $321.50^{c} \pm 0.87$ & $303.70^{b} \pm 0.93$ & $290.20^{c} \pm 0.92$ & $255.40^{\mathrm{d}} \pm 1.05$ & $228.80^{\mathrm{d}} \pm 0.78$ \\
\hline VII & $\mathrm{O}+\mathrm{D}+\mathrm{Cr}+\mathrm{I}$ & $90.80^{f} \pm 0.74$ & $308.80^{\mathrm{d}} \pm 0.78$ & $290.20^{c} \pm 0.92$ & $255.40^{\mathrm{f}} \pm 1.05$ & $228.80^{\mathrm{f}} \pm 0.78$ & $181.20^{\mathrm{f}} \pm 0.72$ \\
\hline VIII & $\mathrm{O}+\mathrm{D}+\mathrm{As}+\mathrm{Cr}$ & $102.40^{\text {cd }} \pm 0.65$ & $325.70^{c} \pm 0.90$ & $305.30^{b} \pm 0.94$ & $292.30^{c} \pm 0.88$ & $275.10^{b} \pm 0.99$ & $252.40^{\mathrm{b}} \pm 1.21$ \\
\hline IX & $\mathrm{O}+\mathrm{D}+\mathrm{As}+\mathrm{Cr}+\mathrm{I}$ & $91.30^{f} \pm 0.73$ & $324.60^{c} \pm 0.71$ & $290.90^{c} \pm 0.79$ & $265.00^{\mathrm{e}} \pm 0.93$ & $238.10^{\mathrm{e}} \pm 0.78$ & $193.40^{\circ} \pm 1.13$ \\
\hline
\end{tabular}

Data are presented as mean \pm SEM, $n=10$. Data were analysed by one-way ANOVA followed by Tukey's post-hoc test. Mean values with different superscripts within the same column are statistically significantly $(\mathrm{p}<0.05)$.

pilot experiment and earlier study performed in our laboratory (Pathak 2019). Streptozotocin (STZ) was dissolved in freshly prepared $0.1 \mathrm{M}$ citrate buffer $(\mathrm{pH}$ 4.5) and the buffer solution was injected intraperitoneally in rats to produce diabetes. Because pancreatic beta cells secrete insulin at high level following STZ injection, 10 $\%$ glucose solution was added to the drinking water of rats for next $24 \mathrm{~h}$ to avoid hypoglycemic shock. Seventytwo hours after injection of STZ, blood samples were collected for estimation of glucose using Accu-Chek Performa Glucometer (Roche diagnostics, USA). Rats with the glucose level of more than $200 \mathrm{mg} / \mathrm{dl}$ was considered as diabetic and further used for the study.

\section{Estimation of biochemical parameters}

Blood samples were collected periodically (on day 1, $3,15,30,45$ and 60 after induction of diabetes) as well as at the end of the experimental period (on $150^{\text {th }}$ day) from the rats of different experimental groups. Blood was collected through retro-orbital plexus from the inner canthus of the eye under anaesthesia (xylazine-ketamine) using capillary tubes or cardiac puncture under light ether anaesthesia. Blood samples from different treatment groups collected at different time interval following overnight fasting of animals were subjected to glucose estimation using Accu-Chek Performa, Roche glucometer and serum biochemical parameters, namely- blood urea nitrogen (BUN), uric acid and creatinine using commercially available kits (Span Diagnostic Ltd., India). The urine samples collected at the end of experiments were also used for estimation of creatinine and albumin level using commercially available kits. The biochemical parameters were estimated with the help of semi autoanalyser (Erba, USA) or UV-VIS spectrophotometer (ECIL, India).

\section{mRNA expression study}

At the end of experimental period, kidney samples from rats of different groups were collected in $0.1 \%$ diethyl pyrocarbonate (DEPC) treated autoclaved PBS. After removing the adjacent fat and washing off the blood, the tissue samples were quickly snap-frozen in liquid nitrogen and stored in RNA later at $-80^{\circ} \mathrm{C}$ until further use. Total RNA was isolated using TRI reagent (Ambion, Thermo scientific) by following manufacturer's instruction. The samples were treated with RNase free DNase and DNase was subsequently inactivated by heating at $56^{\circ} \mathrm{C}$ for $10 \mathrm{~min}$ and immediately chilled at $4^{\circ} \mathrm{C}$. The purity of RNA was checked by biophotometer (Eppendorf, USA). cDNA synthesis (from $1000 \mathrm{ng}$ total RNA) was carried out from the mRNA present in the total RNA using Revertaid® First strand cDNA synthesis kit (Thermo Scientific, USA) using moloney murine leukemia viral reverse transcriptase enzyme by following the manufacturer's instructions.

Real-Time RT-PCR was performed using SYBR Green master mix (PowerUpTM SYBRTM Green master mix [2X]; ThermoFischer Scientific, USA). Each sample was run in duplicate in $10 \mu \mathrm{l}$ reaction. The $10 \mu \mathrm{l}$ reaction mixture consisted of $5 \mu \mathrm{l} \mathrm{SYBR}$ Green master mix, 0.25 
Table 4. Effect of pre-exposure to arsenic and chromium either alone or in combination as well as the effect of ITK formulation on serum level of kidney function test parameters in type- 2 obese diabetic rats.

\begin{tabular}{|c|c|c|c|c|}
\hline Group & Description & $\begin{array}{c}\text { BUN } \\
(\mathrm{mg} / \mathrm{dl})\end{array}$ & $\begin{array}{l}\text { Uric acid } \\
(\mathrm{mg} / \mathrm{dl})\end{array}$ & $\begin{array}{l}\text { Creatinine } \\
(\mathrm{mg} / \mathrm{dl})\end{array}$ \\
\hline I & $\mathrm{C}$ & $20.12^{\mathrm{f}} \pm 1.20$ & $1.99^{\mathrm{c}} \pm 0.19$ & $0.51^{\mathrm{f}} \pm 0.05$ \\
\hline II & $\mathrm{O}$ & $29.06^{\mathrm{d}} \pm 1.49$ & $2.70^{c} \pm 0.21$ & $0.52^{\mathrm{f}} \pm 0.06$ \\
\hline III & $\mathrm{O}+\mathrm{D}$ & $35.95^{\mathrm{bc}} \pm 0.71$ & $5.76^{\mathrm{b}} \pm 0.12$ & $3.41^{\mathrm{ab}} \pm 0.15$ \\
\hline IV & $\mathrm{O}+\mathrm{D}+\mathrm{As}$ & $44.77^{\mathrm{a}} \pm 2.56$ & $8.27^{\mathrm{a}} \pm 0.21$ & $4.07^{\mathrm{a}} \pm 0.24$ \\
\hline $\mathrm{V}$ & $\mathrm{O}+\mathrm{D}+\mathrm{As}+\mathrm{I}$ & $30.22^{\mathrm{cd}} \pm 1.97$ & $5.74^{\mathrm{b}} \pm 0.22$ & $2.81^{b c} \pm 0.19$ \\
\hline VI & $\mathrm{O}+\mathrm{D}+\mathrm{Cr}$ & $27.31^{\mathrm{de}} \pm 1.21$ & $4.86^{\mathrm{b}} \pm 0.60$ & $2.07^{\text {de }} \pm 0.16$ \\
\hline VII & $\mathrm{O}+\mathrm{D}+\mathrm{Cr}+\mathrm{I}$ & $21.22^{\mathrm{ef}} \pm 1.07$ & $2.74^{\mathrm{c}} \pm 0.26$ & $1.40^{\mathrm{e}} \pm 0.13$ \\
\hline VIII & $\mathrm{O}+\mathrm{D}+\mathrm{As}+\mathrm{Cr}$ & $38.17^{\mathrm{ab}} \pm 1.40$ & $5.18^{\mathrm{b}} \pm 0.24$ & $2.17^{\mathrm{cd}} \pm 0.16$ \\
\hline IX & $\mathrm{O}+\mathrm{D}+\mathrm{As}+\mathrm{Cr}+\mathrm{I}$ & $26.03^{\mathrm{def}} \pm 1.22$ & $5.00^{\mathrm{b}} \pm 0.36$ & $1.80^{\mathrm{e}} \pm 0.14$ \\
\hline
\end{tabular}

Data are presented as mean \pm SEM, $n=10$. Data were analysed by one-way ANOVA followed by Tukey's post-hoc test. Mean values with different superscripts within the same column are statistically significantly $(\mathrm{p}<0.05)$.

$\mu \mathrm{l}$ from $10 \mathrm{pmol} / \mu \mathrm{l}$ stock solution of each of the genespecific forward and reverse primers, and $1.0 \mu \mathrm{l}$ of cDNA and volume was adjusted to $10 \mu \mathrm{l}$ with nuclease free water (NFW). The real-time PCR reaction was started with initial incubation at $95^{\circ} \mathrm{C}$ for 2 min followed by 42 cycles of amplification with denaturation at $95^{\circ} \mathrm{C}$ for $15 \mathrm{sec}$, annealing (temperature as mentioned in Table 2 for gene specific primer pairs) for $15 \mathrm{sec}$ and extension at $72{ }^{\circ} \mathrm{C}$ for $60 \mathrm{sec}$ each. To assess the specificity of the amplified product, dissociation curve was generated at temperature of $60^{\circ} \mathrm{C}$ through $95^{\circ} \mathrm{C}$. The results were expressed as threshold cycle values (CT).

\section{Statistical analysis}

Results were expressed as mean \pm SEM with ' $n$ ' equal to number of animals used in the respective experimental protocols. The mean values from different groups were analyzed by one-way ANOVA followed by Tukey's posthoc test using Graph-Pad Prism version 4.0 software.

To study the relative change in gene expression, the $2^{-\triangleleft \triangleleft \mathrm{CT}}$ method was used as described previously by Livak and Schmittgen (2001). The formula used to calculate the fold change in gene expression was "fold change = $2^{-\triangleleft \triangleleft} \mathrm{CT}, "\left[\right.$ where ${ }^{\triangleleft \triangleleft} \mathrm{C}_{\mathrm{T}}=\left(\mathrm{CT}\right.$, target gene $\left.-\mathrm{C}_{\mathrm{T}}, \mathrm{GAPDH}\right)$ treatment - $\left(\mathrm{C}_{\mathrm{T}}\right.$, target gene $-\mathrm{C}_{\mathrm{T}}$, GAPDH) control]. The gene-specific amplification was corrected for the difference in input of RNA by taking housekeeping gene GAPDH to account. For treatment groups, evaluation of $2^{-\triangleleft \triangleleft} \mathrm{CT}$ indicates the fold change in gene expression relative to healthy control (i.e., fold change in healthy control = 1 ). The results were analyzed in comparison with the $C_{T}$ (minimum threshold of amplification) value of the target gene and the reference gene (GAPDH).

\section{RESULTS AND DISCUSSION}

Diabetes mellitus is a metabolic syndrome characterized by defective control over plasma glucose either due to insulin deficiency or insulin resistance (Ferrannini 1998, Ye 2013). As per the epidemiological survey more than 350 million people around the world were affected by this widespread chronic disease in 2011 and its prevalence is expected to increase to approximately 550 million by 2030 (Whiting et al.2011). Insulin resistance is central to development of type 2 diabetes mellitus and is commonly associated with heart disease, stroke, nephropathy, retinopathy and neuropathy. Current therapeutic approaches of diabetes have shown certain limitations, thus developing an alternative and potential therapeutic strategies become a thrust area of research for the scientific fraternity. Ethnopharmacological approach provides low cost, long lasting therapeutic potential to treat diabetes mellitus and its associated complications. In the present study, we have investigated the effect of pre-exposure to arsenic (As) and chromium $(\mathrm{Cr})$ on type- 2 diabetes associated cardiovascular and renal dysfunctions and efficacy of ITK formulation against these complications.

Streptozotocin leads to production of antibodies which in turn causes apoptosis of pancreatic $\beta$-cells leading to impaired insulin synthesis and secretion (Simsek et al. 2012, Boslem et al. 2012). Fasting blood glucose levels $(\mathrm{mg} / \mathrm{dl})$ of rats from different groups on day $0,3,15,30$, 
45, 60 after administration of streptozotocin (STZ @ 30 $\mathrm{mg} / \mathrm{kg}$ b.wt, i.p.) are summarized in Table 3. Perusal of the data revealed that STZ administration significantly increased the fasting blood glucose level throughout the experimental period in the rats from Gr-III as compared to that observed in obese control (Gr-II) or healthy control (Gr-I) groups and these values were found to be more than $200 \mathrm{mg} / \mathrm{dl}$. Pre-exposure to arsenic before induction of diabetes by STZ administration in Gr-IV rats further significantly $(\mathrm{p}<0.05)$ increased the fasting blood glucose level as compared to that observed in obese diabetic rats (Gr-III). However, pre-exposure to chromium either alone or in combination with arsenic significantly reduced the blood glucose level from 30th day onward, albeit, the level of the blood glucose in these animals were still found to be higher ( $>200 \mathrm{mg} / \mathrm{dl})$. Treatment with ITK in Gr-V, VII and IX significantly reduced the fasting blood glucose level from $30^{\text {th }}$ day onward as compared to respective control (i.e. Gr-IV, VI and VIII, respectively). In consistent to the present observation, Rebecca et al. (2016) reported the efficacy of chromium in improving glycemic control by lowering blood sugar level. Further, chromium is reported to activate insulin receptor kinase and inhibit the insulin receptor phosphatase enzyme leading to increase in the phosphorylation of insulin and enhancement in the sensitivity (Davis et al. 1996).

Diabetic nephropathy is a severe complication of diabetes and the leading cause of death due to end-stage renal disease (ESRD). About 30\% of diabetic patients suffer from kidney disease, proteinuria, and other severe symptoms, and eventually develop diabetic nephropathy and $53 \%$ of patients die from ESRD (Ge et al. 2019). The effect of different treatments on kidney function tests in the present study is summarized in Table 4. Perusal of the data revealed that, serum biochemical parameters related to kidney function test viz. blood urea nitrogen (BUN), uric acid and creatinine levels were significantly $(p<0.05)$ increased in the obese diabetic rats $(\mathrm{Gr}-\mathrm{III})$ as compared to healthy control (Gr-I) or obese control (GrII) rats. Pre-exposure to arsenic in obese diabetic rats (Gr-IV) further significantly increased the BUN and uric acid level without further increasing the creatinine level as compared to obese diabetic rats (Gr-III), although these values were found to be still significantly higher in comparison to that observed in healthy control or obese control animals. Treatment with ITK formulation for 60 days significantly improved these kidney function test parameters (Table 4). Pre-exposure to chromium (GrVI) significantly $(\mathrm{p}<0.05)$ decreased the BUN and creatinine level in the serum of obese diabetic rats as compared to obese diabetic control (Gr-III) and ITK
Table 5. Effect of oral administration of ITK formulation for 60 days on urine level of albumin and creatinine in type2 obese diabetic rats pre-exposed to arsenic and chromium either alone or in combination for 90 days.

\begin{tabular}{lllc}
\hline Group & Description & $\begin{array}{l}\text { Albumin } \\
(\mathbf{g} / \mathbf{d l})\end{array}$ & $\begin{array}{c}\text { Creatinine } \\
(\mathbf{m g} / \mathbf{d l})\end{array}$ \\
\hline I & C & $1.60^{\mathrm{g}} \pm 0.19$ & $22.05^{\mathrm{e}} \pm 0.96$ \\
II & $\mathrm{O}$ & $2.45^{\mathrm{g}} \pm 0.41$ & $37.45^{\mathrm{d}} \pm 1.02$ \\
III & $\mathrm{O}+\mathrm{D}$ & $15.75^{\mathrm{ab}} \pm 0.61$ & $49.27^{\mathrm{c}} \pm 0.81$ \\
IV & $\mathrm{O}+\mathrm{D}+\mathrm{As}$ & $18.69^{\mathrm{a}} \pm 0.89$ & $75.09^{\mathrm{a}} \pm 1.52$ \\
V & $\mathrm{O}+\mathrm{D}+\mathrm{As}+\mathrm{I}$ & $13.76^{\mathrm{bc}} \pm 0.78$ & $57.56^{\mathrm{b}} \pm 1.50$ \\
VI & $\mathrm{O}+\mathrm{D}+\mathrm{Cr}$ & $9.47^{\mathrm{de}} \pm 0.78$ & $35.46^{\mathrm{d}} \pm 1.05$ \\
VII & $\mathrm{O}+\mathrm{D}+\mathrm{Cr}+\mathrm{I}$ & $4.09^{\mathrm{fg}} \pm 0.62$ & $22.69^{\mathrm{e}} \pm 0.91$ \\
VIII & $\mathrm{O}+\mathrm{D}+\mathrm{As}+\mathrm{Cr}$ & $12.00^{\mathrm{cd}} \pm 0.77$ & $51.29^{\mathrm{c}} \pm 1.27$ \\
IX & $\mathrm{O}+\mathrm{D}+\mathrm{As}+\mathrm{Cr}+\mathrm{I}$ & $7.01^{\mathrm{ef}} \pm 0.73$ & $38.87^{\mathrm{d}} \pm 0.99$
\end{tabular}

Data are presented as mean \pm SEM, $n=10$. Data were analysed by one-way ANOVA followed by Tukey's post-hoc test. Mean values with different superscripts within the same column are statistically significant $(\mathrm{p}<0.05)$.

treatment further improved these biochemical parameters. Concurrent pre-exposure to arsenic and chromium did not produce further damage to kidney in obese diabetic rats as evident from the non-significant alteration in the serum level of BUN and uric acid with significant improvement in creatinine level as compared to obese diabetic rats (Gr-III). Treatment with ITK further improved the serum level of the parameters related to kidney function test in obese diabetic rats pre-exposed to arsenic and chromium in combination. Decrease in protein and increase in urea and creatinine levels in serum are the markers of kidney dysfunction (Latha and Daisy 2010). The elevated level of urea and creatinine in animal model of diabetes is suggested to be due to altered metabolic status following hyperglycemia and hypoinsulinemia characterized by reduced uptake of amino acids by the tissue, higher rate of proteolysis with reduction in protein synthesis leading to increase in urea production by the liver (Singh et al. 2018, Badawy et al. 2019). In the present study too, STZ produced nephropathy in obese rats as evidenced by the increase in the serum level of BUN, uric acid and creatinine along with corresponding increase in urine creatinine and albumin concentration. Impaired function of membrane barrier in the glomerulus in diabetic nephropathy often leads to increased excretion of albumin in urine, increased serum creatinine, and blood urea nitrogen (Tashiro et al. 2002). 
Table 6. Effect of pre-exposure to arsenic and chromium either alone or in combination as well as the effect of ITK on mRNA expression of cyst-3 in kidney tissue.

\begin{tabular}{llc}
\hline Group & Description & $\begin{array}{c}\text { Cystatin-3 } \\
\text { (Fold Change) }\end{array}$ \\
\hline I & C & $1.59^{\mathrm{a}} \pm 1.24$ \\
II & $\mathrm{O}$ & $55.92^{\mathrm{b}} \pm 7.42$ \\
III & $\mathrm{O}+\mathrm{D}$ & $56.64^{\mathrm{b}} \pm 3.21$ \\
IV & $\mathrm{O}+\mathrm{D}+\mathrm{As}$ & $68.93^{\mathrm{b}} \pm 15.50$ \\
V & $\mathrm{O}+\mathrm{D}+\mathrm{As}+\mathrm{I}$ & $29.89^{\mathrm{a}} \pm 10.27$ \\
VI & $\mathrm{O}+\mathrm{D}+\mathrm{Cr}$ & $3.38^{\mathrm{a}} \pm 2.13$ \\
VII & $\mathrm{O}+\mathrm{D}+\mathrm{Cr}+\mathrm{I}$ & $6.28^{\mathrm{a}} \pm 1.96$ \\
VIII & $\mathrm{O}+\mathrm{D}+\mathrm{As}+\mathrm{Cr}$ & $20.29^{\mathrm{a}} \pm 6.27$ \\
IX & $\mathrm{O}+\mathrm{D}+\mathrm{As}+\mathrm{Cr}+\mathrm{I}$ & $12.04^{\mathrm{a}} \pm 8.01$ \\
\hline
\end{tabular}

Data are presented as mean \pm SEM, $n=4$. Data were analysed by oneway ANOVA followed by Tukey's post-hoc test. Mean values with different superscripts within the same column are statistically significantly $(\mathrm{p}<0.05)$.

Further, to confirm the nephropathic effect, we evaluated the level of albumin and creatinine in the urine of the animals from different groups (Table 5). Perusal of the data revealed that, induction of diabetes in obese rats significantly $(\mathrm{p}<0.05)$ increased the urinary albumin and creatinine level and pre-exposure to arsenic in obese diabetic rats further increased the level as compared to obese control or healthy control. However, pre-exposure to either chromium alone or in combination with arsenic did not produce any significant alteration in the urinary albumin, creatinine level in the obese diabetic rats. Treatment with ITK formulation also did not produce any deleterious effect on urinary albumin, creatinine level.

Cystatin-3/Cyst-c (Cyst-3) is considered to be an early marker of diabetic nephropathy in patients with type-2 diabetes (You et al. 2013). It is a potent inhibitor of liposomal proteinases and probably one of the most important extracellular inhibitors of cysteine proteinase produced by nucleated cells. Cyst-c is freely filtered by the glomerulus and then absorbed by PCT, where it gets catabolised. A small amount of Cyst-3 is secreted in urine whereas its level is reported to be increased markedly during kidney dysfunction with reduced GFR (Lesley and Andrew 2019). To further assess the degree of kidney injury following pre-exposure to arsenic and chromium in obese diabetic rats, the mRNA expression profile of Cyst-3, one of the kidney injury biomarkers, were studied. As summarized in Table 6, the mRNA expression of renal
Cyst-3 gene was significantly $(\mathrm{p}<0.05)$ increased in the obese diabetic rats (Gr-III; $56.64 \pm 3.21$ fold, $n=4$ ). Preexposure to arsenic for 90 days though did not further increase the mRNA expression of Cyst-3 in renal tissue, however, the value was found to be significantly higher as compared to control animals. Unlike arsenic, preexposure to chromium either alone (Gr-VI) or in combination (Gr-VIII) with arsenic did not increase the mRNA expression of Cyst-3 rather these values were found to be significantly lower in comparison to obese diabetic rats (Gr-III). Treatment with ITK further reduced the Cyst-3 level in the obese diabetic rats from the groups that were pre-exposed to arsenic and chromium either alone or in combination. Significant increase in the expression level of Cyst-3 in kidney tissue of rats from obese diabetic rats and/or arsenic pre-exposed obese diabetic rats indicated the presence of kidney dysfunction. Whereas chromium pre-exposure either alone or in combination with arsenic did not significantly increase the Cyst-3 level in comparison to their respective control implying its reno-protective effect. Administration of ITK formulated medicine also produced beneficial effect. The results of the mRNA expression studies of Cyst-3 are well corroborated with the findings related to other biomarkers of kidney injury as described above.

Chromium picolinate, an essential trace element, has long been used to treat type 1 , type 2 , gestational, and steroid-induced diabetes. This is popularly used as nutritional supplement for treating type 2 diabetic patients and diabetes-predisposed individuals (Jana et al. 2009). One of the major advantages of chromium-picolinate is its high stability and bioavailability in comparison to dietary chromium (Bailey et al. 2008). It is well known for its hypoglycemic activity as well as the ability to enhance insulin function and sensitivity (Broadhurst and Domenico 2006, Martin et al. 2008, Huang et al. 2014). However, its reno-protective role against diabetesinduced nephropathy is poorly understood. In the present study we have observed that pre-exposure to chromium significantly reduced the diabetes-induced kidney injury as evidenced from the findings of biochemical parameters. Recently, beneficial effect of chromium in diabetic nephropathy is also reported where the reno-protective effect of chromium picolinate was suggested to be attributed to its anti-oxidant potential and inhibition of TGF- $\beta 1 /$ Smad2/3 expression (Qi et al. 2020). Possible existence of such mechanism in chromium-induced protective effect thus cannot be ruled out. Administration of ITK formulation also reduced the kidney damage produced by diabetes and/or arsenic-induced nephropathy in obese diabetic rats. 


\section{CONCLUSION}

Based on the above findings, it may be concluded that pre-exposure to arsenic aggravated the kidney damage in obese diabetic rats while pre-exposure to chromium picolinate exhibited nephro-protective effect. Further, when chromium was administered concurrently with arsenic, it reduced the arsenic-induced damage to the kidney. This reno-protective effect of chromium was attributed to its ability to improve the specific biomarkers of renal injury, besides reducing the mRNA expression of cystatin-3. Administration of ITK formulation also enhanced the nephroprotective role of chromium.

\section{REFERENCES}

Ahmad A, Husain A, Mujeeb M, Khan SA, Najmi AK et al. (2013) A review on therapeutic potential of Nigella sativa: A miracle herb. Asian Pac J Trop Biomed 3(5): 337-352.

Ali BH, Ziada A, Blunden G (2009) Biological effects of gum arabic: a review of some recent research. Food Chem Toxicol 47(1): 1-8.

Badawy RE, Ibrahim KA, Hassan NS, El-Sayed WM (2019) Pterocarpus santalinus ameliorates streptozotocininduced diabetes mellitus via anti-inflammatory pathways and enhancement of insulin function. Iran J Basic Med Sci 22(8): 932-939.

Bailey MM, Sturdivant J, Jernigan PL, Townsend MB, Bushman J et al. (2008) Comparison of the potential for developmental toxicity of prenatal exposure to two dietary chromium supplements, chromium picolinate and $[\mathrm{Cr} 3 \mathrm{O}$ $(\mathrm{O} 2 \mathrm{CCH} 2 \mathrm{CH} 3)\left(6(\mathrm{H} 2 \mathrm{O})_{3}\right]^{+}$, in mice. Birth Defects Res Dev Reprod Toxicol 83(1): 27-31.

Behall KM, Scholfield DJ, Hallfrisch JG (2006) Barleyglucan reduces plasma glucose and insulin responses compared with resistant starch in men. Nutr Res 26: 644-50.

Boslem E, Meikle PJ, Biden TJ (2012) Roles of ceramide and sphingolipids in pancreatic $\beta$-cell function and dysfunction. Islets 4(3): 177-187.

Broadhurst CL, Domenico P (2006) Clinical studies on chromium picolinate supplementation in diabetes mellitus-a review. Diabetes Technol Ther 8(6): 677-687.

Davis CM, Sumrall KH, Vincent JB (1996) A biologically active form of chromium may activate a membrane phosphotyrosine phosphatase (PTP). Biochemistry 35: 1296312969.

El-Nagar DM (2017) Pancrease-protective effects of arabic gum on Diabetic type2 Streptozotocin-induced in Albino mice. Res J Pharm Biol Chem Sc 8(1): 1263-1270.
Ferrannini E (1998) Insulin resistance versus insulin deficiency in non-insulin-dependent diabetes mellitus: problems and prospects. Endocr Rev 19(4): 477-490.

Ge CX, Xu MM, Qin YT, Gu TT, Lou DS et al. (2019) Fisetin supplementation prevents high fat diet-induced diabetic nephropathy by repressing insulin resistance and RIP3-regulated inflammation. Food Funct 10: 2970-2985.

Ghosh PK, Sahoo B (2011) Indigenous traditional knowledge. Orissa Review 65-70.

Grover J, Yadav S, Vats V (2002) Medicinal plants of India with anti-diabetic potential. J Ethnopharmacol 81: 81-100.

Huang S, Peng W, Jiang X (2014) The effect of chromium picolinate supplementation on the pancreas and macroangiopathy in type II diabetes mellitus rats. J Diabetes 5: 717-729.

Jana M, Rajaram A, Rajaram R (2009) Chromium picolinate induced apoptosis of lymphocytes and the signaling mechanisms thereof. Toxicol Appl Pharmacol 237(3): 331-344.

Khan AR, Awan FR (2014) Metals in the pathogenesis of type 2 diabetes. J Diabetes Metab Disord 13(1): 16.

Latha RC, Daisy P (2010) Parameters in Streptozotocin diabetic rats. Int J Pharmacol 6(2): 89-96.

Lee NY, Kim YK, Choi I, Cho SK, Hyun JN et al. (2010) Biological activity of barley (Hordeum vulgare) and barley byproduct extracts. Food Sci Biotechnol 19: 785-791.

Lesley AI, Andrew SL (2019) Knowing your GFR when the number is not (exactly) the number. Kidney Int 96: 280-282.

Livak KJ, Schmittgen TD (2001). Analysis of relative gene expression data using real-time quantitative PCR and the 2- $\triangleleft$ đct method. Methods 25: 402-408.

Lizicarova D, Krahulec B, Hirnerova E, Gaspar L, Celecova Z (2014) Risk factors in diabetic nephropathy progression at present. Bratisl Lek Listy 115(8): 517-521.

Martin J, Wang ZQ, Zhang XH (2008) Chromium picolinate supplementation attenuates body weight gain and increases insulin sensitivity in subjects with type 2 diabetes. Diabetes Care 8: 1826-1832.

Nicolle E, Souard F, Faure P, Boumendjel A (2011) Flavonoids as promising lead compounds in type 2 Diabetes mellitus: molecules of interest and structure activity relationship. Curr Med Chem 18: 2661-2672.

Pandey V, Mittal R, Sharma P (2017) Documentation and application of indigenous traditional knowledge (ITK) for sustainable agricultural development. AJAEES 15(3): 1-9. 
Pathak A (2019) Studies on testicular activity of type II diabetic rats following concurrent pre-exposure to Arsenic and Chromium. M.V.Sc thesis submitted to U. P. Pandit Deen Dayal Upadhyaya Pashu Chikitsa Vigyan Vishwavidyalaya Evam GoAnusandhan Sansthan (DUVASU), Mathura (Uttar Pradesh), India.

Qi SS, Zheng HX, Hai Jiang, Li PY, Le CD (2020) Regioselective catalytic asymmetric $\mathrm{N}$-alkylation of isoxazol5-ones with para-quinone methides. Org Biomol Chem 18(13): 2398-2404.

Rebecca BC, Johanna TD, Regan LB (2016) Chromium supplements for glycemic control in type 2 diabetes: limited evidence of effectiveness. Nutr Rev 74(7): 455-468.

Reed MJ, Meszaros K, Entes LJ, Claypool MD, Pinkett JG et al. (2000) A new rat model of type 2 diabetes: the fat-fed, streptozotocin-treated rat. Metabolism 49(11): 1390-1394.

Schena FP, Gesualdo L (2005) Pathogenetic mechanisms of diabetic nephropathy. J Am Soc Nephrol 16(S1): S30-S33.

Simsek N, Kaya M, Kara A, Can I, Karadeniz A et al. (2012) Effects of melatonin on islet neogenesis and beta cell apoptosis in streptozotocin-induced diabetic rats: an immunohistochemical study. Domest Anim Endocrinol 43(1): 47-57.

Singh A, Srivastav R, Pandey AK (2018) Effect of the seeds of Terminalia chebula on blood sugar, lipid profile and urine parameters in STZ induced diabetic rats. J Pharmacogn Phytochem 7(2): 1-5.

Somwar R, Koterski S, Sweeney GA (2002) Dominant negativep38 MAPK mutant and novel selective inhibitors of p38 MAPK reduce insulin-stimulated glucose uptake in 3T3L1 adipocyte without affecting GLUT4 translocation. J Biol Chem 277: 50386-50395.

Srinivasan K, Viswanad B, Asrat L, Kaul CL, Ramarao P (2005) Combination of high-fat diet-fed and low-dose streptozotocin-treated rat: a model for type 2 diabetes and pharmacological screening. National Library of Medicine Pharmacol Res 52(4): 313-320.

Sriwijitkamol A, Christ-Roberts C, Berria R (2006) Reduced skeletal muscle inhibitor of kappa-B $\beta$ content is associated with insulin resistance in subjects with type 2 diabetes: reversal by exercise training. Diabetes 55: 760-767.

Suman RK, Borde MK, Mohanty IR, Maheshwari U, Deshmukh YA (2016) Myocardial salvaging effects of berberine in experimental diabetes co-existing with myocardial infarction. J Clin Diagn Res 10(3): FF13-18.

Suzuki Y, Jin C, Yazawa I (2014) Cystatin C triggers neuronal degeneration in a model of multiple system atrophy. Am J Pathol 184(3): 790-799.

Tanios BY, Ziyadeh FN (2012) Emerging therapies for diabetic nephropathy patients: beyond blockade of the reninangiotensin system. Nephron Extra 2(1): 278-282.

Tashiro K, Koyanagi I, Saitoh A, Shimizu A, Shike T et al. (2002) Urinary levels of monocyte chemoattractant protein-1 (MCP-1) and interleukin-8 (IL-8), and renal injuries in patients with type 2 diabetic nephropathy. J Clin Lab Anal 16: 1-4.

Tripathi BK, Srivastava AK (2006) Diabetes mellitus: complications and therapeutics. Med Sci Monit 12(7): 130-147.

Turchetti AP, da Costa LF, Romão Ede L, Fujiwara RT, da Paixão TA et al. (2015) Transcription of innate immunity genes and cytokine secretion by canine macrophages resistant or susceptible to intracellular survival of Leishmania infantum. Vet Immunol Immunopathol 163(1-2): 67-76.

Vaher M Zielinski, Matso K, Levandi T, Helmja K, Kaljurand M (2010) Phenolic compounds and the antioxidant activity of the bran, flour and whole grain of different wheat varieties. Procedia Chem 2(1): 76-82.

Walton FS, Harmon AW, Paul DS, Drobna Z, Patel YM et al. (2004). Inhibition of insulin dependent glucose uptake by trivalent arsenicals: possible mechanism of arsenic induced diabetes. Toxicol Appl Pharmacol 198: 424-433.

Ward JL, Poutanen K, Gebruers K (2008) The health grain cereal diversity screen: concept, results, and prospects. J Agric Food Chem 56(21): 9699-9709.

Whiting DR, Guariguata L, Weil C, Shaw J (2011) IDF diabetes atlas: global estimates of the prevalence of diabetes for 2011 and 2030. Diabetes Res Clin Pract 94(3): 311-321.

You SL, Hsu WL, Yang HI, Lee MH, Chen HC et al. (2013) Cystatin $\mathrm{C}$ is a biomarker for predicting acute kidney injury in patients with acute-on-chronic liver failure. World J Gastroenterol 19(48): 9432-9438.

Zimmet P, Alberti KG, Shaw J (2001) Global and societal implications of the diabetes epidemic. Nature 414(6865): 782787.

*Cite this article as: Saif M, Akash R, Yadav VP, Singh R, Prakash A, Shukla A, Choudhury S (2021) Chromium and ITK formulation diminish arsenic-induced kidney in obese type-2 diabetic rats. Explor Anim Med Res 11(2): 205213. DOI : $10.52635 /$ eamr/11.2.205-213. 